\title{
R-Cadherin Expression during Nucleus Formation in Chicken Forebrain Neuromeres
}

\author{
Susanne I. I. Gänzler and Christoph Redies \\ Department of Biochemistry, Max Planck Institute for Developmental Biology, D-72072 Tübingen, Germany
}

The primordial neuroepithelium of the vertebrate forebraiı consists of transverse and longitudinal morphogenetic compartments ('neuromeres"). During development, neurons born in the ventricular zone of each neuromere migrate outward to the mantle zone. Here, neuroblasts gradually accumulate and aggregate either into sheets ("laminae") or into roundish structures ("'nuclei"). As brain architecture matures, sets of nuclei and laminae derived from several neuromeres become connected by fiber tracts to form functional circuits. We show by immunostaining and in situ hybridization techniques that, in the E3-E5 chicken embryo, the cell adhesion molecule R-cadherin is expressed in several stripes and patches in the forebrain neuroepithelium. This expression pattern reflects, at least in part, the neuromeric organization of the forebrain. For example, in both the ventral and dorsal thalamus, R-cadherin expression has a sharp border at the respective caudal neuromere boundary. Moreover, focusing on the mid-hypothalamic region, we demonstrate that a subset of postmitotic neuroblasts in the ventricular zone express R-cadherin during their migration to the mantle zone, where they aggregate into particular nuclei. In the mantle zone, R-cadherin-expressing neuroblasts accumulate in parallel with neuroblasts expressing another cadherin, $\mathrm{N}$-cadherin. The two types of cells segregate from each other to form adjacent nuclei. Some of the R- and the N-cadherin-positive nuclei form parts of particular functional circuits in the mature brain. In conclusion, our results suggest that cadherins play a role in the formation of brain nuclei and in the developmental transformation from neuromeric to functional organization in the vertebrate forebrain.

[Key words: pattern formation, segmentation, brain nucleus, calcium-dependent cell-cell adhesion, neuroblast migration, neural differentiation]

The primordial epithelium of the vertebrate neural tube is transiently partitioned into numerous transverse and longitudinal domains ("neuromeres") (von Baer, 1828; Palmgren, 1921; Ren-

\footnotetext{
Received Dec. 8, 1994; accepted Jan. 24, 1995.

We are grateful to V. Kastner for expert technical assistance, to M. Takeichi, E. de la Rosa, U. Dräger, and H. Fujisawa for their kind gifts of antibodies and cDNAs, to P. G. Layer and B. Weiss for help with the AChE staining teclunique, to $J$. Berger for assistance with the scanning electron microscopy, to $\mathrm{K}$. Arndt and T. Voigt for anatomical suggestions, to J. Jung for assistance with image processing, to $\mathrm{V}$. Kastner and R. Bishop for improving the syntax, and to U. Schwarz for comments and generous support of this study. This work was supported by the Max Planck Society.

Correspondence should be addressed to Dr. C. Redies, Department of Biochemistry, Max Planck Institute for Developmental Biology, Postfach 2109 , D- 72011 Tübingen, Germany.

Copyright (C) 1995 Society for Neuroscience $0270-6474 / 95 / 154157-16 \$ 05.00 / 0$
}

dahl, 1924; Vaage, 1969; Kuhlenbeck, 1973; Puelles et al., 1987; Puelles and Rubenstein, 1993) that represent independent morphogenetic fields (Bergquist and Källén, 1953a,b, 1954; Keyser, 1972; Puelles et al., 1987). The boundaries between neuromeres often coincide with primordial fiber tracts and restrict cell lineage and migration. Generally, they coincide with the borders of expression of gene regulatory proteins (reviewed in Lumsden, 1990, 1993; Figdor and Stern, 1993; Krumlauf et al., 1993; Puelles and Rubenstein, 1993; Wilson et al., 1993).

During development, a percentage of cells born in the proliferative (ventricular) zone of each neuromere become postmitotic and migrate as neuroblasts outward into the mantle zone (Sauer, 1935; Fujila, 1964; Morest, 1970) in two or three sustained waves of migration (Bergquist, 1957). In the mantle zone, neuroblasts either accumulate in sheets ("laminae"), for example, in the cerebellar and cerebral cortices, or they aggregate into roundish structures ("nuclei"), for example, in the diencephalon (Palmgren, 1921; Rendah1, 1924; Kuhlenbeck, 1937; Rose, 1942; Keyser, 1972; Altman and Bayer, 1978). Particular nuclei and laminae derived from several neuromeres become selectively connected to each other by fiber tracts, sometimes over considerable distances, to form functional systems and circuits.

While the molecular and developmental processes leading to the development of laminated gray matter structures and fiber tracts have been under intense investigation (for reviews, see Rakic, 1972; Hatten, 1990, 1993; Goodman and Shatz, 1993; Rakic et al., 1994), little is known about the mechanisms and molecules regulating the formation of nuclei in the vertebrate CNS.

We have recently demonstrated that two cell-cell adhesion molecules, $\mathrm{N}$ - and R-cadherin (Hatta et al., 1988; Inuzuka et al., 1991), are expressed by particular di- and mesencephalic nuclei and fiber tracts in the developing chicken brain (Redies et al., 1993). Cadherins are cell surface molecules that regulate morphogenesis in a $\mathrm{Ca}^{2+}$-dependent manner in a variety of tissues (reviewed in Takeichi, 1988; Ranscht, 1991; Geiger and Ayalon, 1992; Pouliot, 1992; Grunwald, 1993). Numerous in vitro experiments and in vivo observations show that cadherins can mediate the aggregation and sorting of cells (Nose and Takeichi, 1986; Hatta et al., 1987; Nagafuchi et al., 1987; Nose et al., 1988; Miyatani et al., 1989; Inuzuka et al., 1991). Based on these findings, we postulated that $\mathrm{N}$ - and R-cadherin might also regulate the formation and segregation of developing nuclei in the embryonic brain (Redies et al., 1993). The present study provides support for this hypothesis. By focusing on the expression of $\mathrm{R}$-cadherin in the forebrain of the chicken embryo, we demonstrate that, at early stages of development (E3-E5), $\mathrm{R}$-cadherin is expressed in several forebrain neuromeres in a 

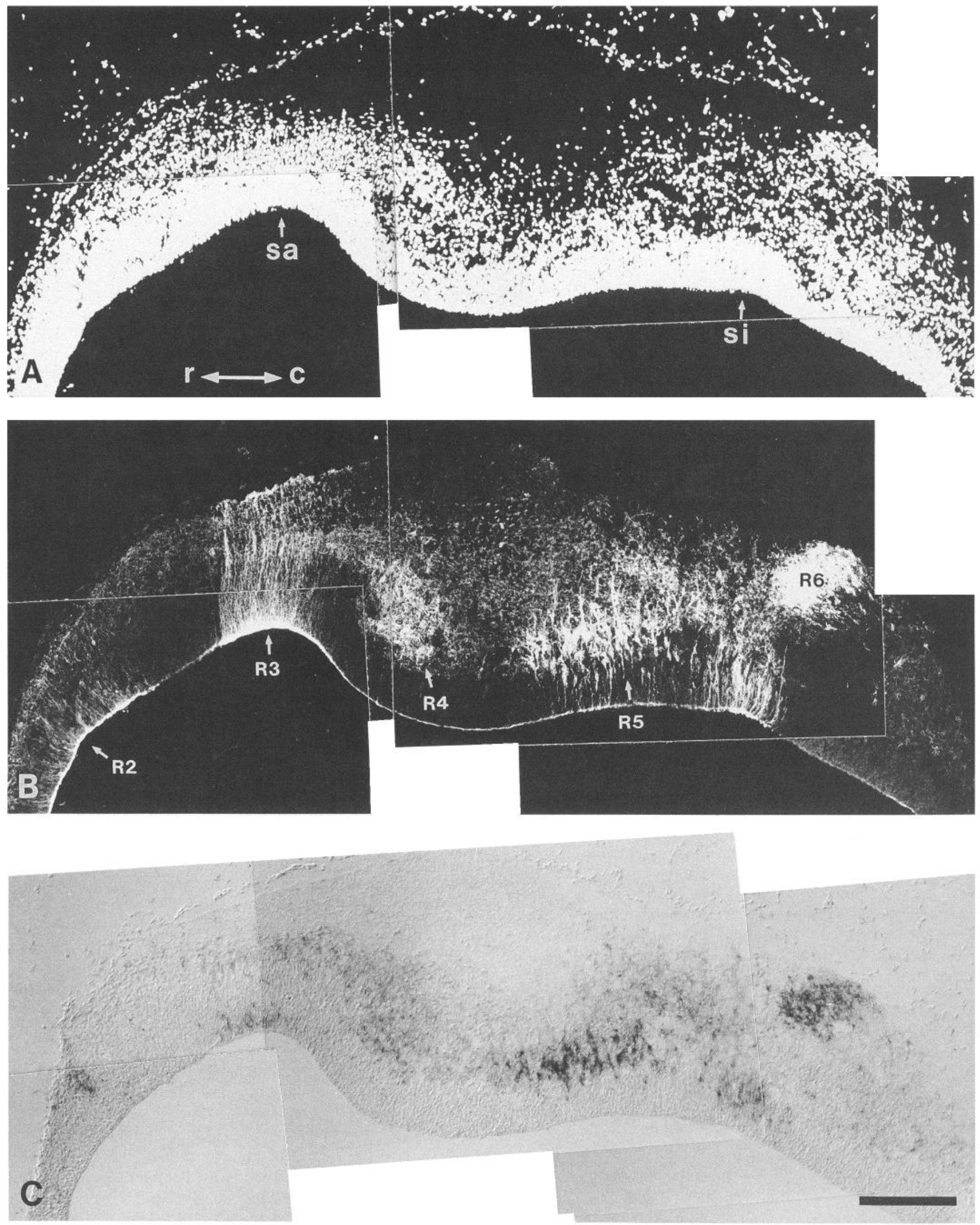

Figure 1. Transverse sections through the hypothalamus of a chicken embryo of $5 \mathrm{~d}$ incubation (E5). A, Section stained with nuclear dye Hoechst 33258. The ventricular zone is characterized by a high density of cellular nuclei. In the mantle zone, cellular nuclei are spaced farther apart. $B$, Section immunostained for R-cadherin. $C$, Nomarski optical image of a section hybridized in situ with digoxigenin-labeled antisense RNA probe 
stripe-like or patchy fashion. Most of these regions later give rise to R-cadherin-positive nuclei and fiber tracts (Redies et al., 1993; Arndt and Redies, unpublished observations). In one particular forebrain region, the mid-hypothalamic region (Kuenzel and van Tienhoven, 1982), we studied R-cadherin-expressing neuroblasts during their migration and aggregation into particular nuclei in detail.

This work has been published in preliminary form (Redies and Gänzler, 1994).

\section{Materials and Methods}

Animals and antibodies. Fertilized Hisex chicken eggs (Gallus domesticus) were incubated at $37^{\circ} \mathrm{C}$ and $65 \%$ humidity in a forced-draft incubator. Embryos were staged according to Hamburger and Hamilton (1951). Embryos of 2-8 d incubation (E2-E8) were used. The stages were E2 (HH19), E3.5 (HH21), E4 (HH24), E4.5 (HH26), E5 (HH27), E6 ( $\mathrm{HH} 29)$, E7 (HH31), and E8 (HH34).

For immunohistochemistry, the following antibodies were used: mouse monoclonal antibody RCD-2 against chicken R-cadherin (Redies et al., 1992); mouse monoclonal antibody 29B8 against the $160 \mathrm{kDa}$ subunit of chicken neurofilament (IIatta et al., 1987) (generous gift of II. Fujisawa); mouse monoclonal antibody R5, which is directed against a vimentinassociated protein in radial glia (Dräger et al., 1984; Vanselow et al., 1989) (generous gift of U. Dräger); a mouse monoclonal antibody against bromodeoxyuridine (BrdU) (Bioscience Products, Switzerland); and a rabbit polyclonal antibody against $\mathrm{Ng}$-CAM/8D9/G4 (Grumet and Edelman, 1984; Rathjen et al., 1987; Grumet, 1992; Lemmon and McLoon, 1986) obtained as described previously (de la Rosa et al., 1990) (generous gift of E. de la Rosa). Commercially available secondary antibodies appropriately labeled with FITC, Cy3, or biotin (Jackson ImmunoResearch Laboratories) were used to detect primary antibodies. Biotinylated secondary antibodies were visualized with FITC-labeled streptavidin (Jackson ImmunoResearch Laboratories). For whole-mount immunostaining, the antibody RCD-2 was detected with biotinylated secondary antibody, followed by avidine and biotinylated horseradish peroxidase complex (ABC Elite kit, Vector Laboratories).

Whole-mount immunostaining. For whole-mount immunostaining, heads of E3, E4, E5, E6, and E7 embryos were fixed in $4 \%$ formaldehyde/HBSS for 1-2 hr on ice. To improve accessibility of brain tissue for antibodies, heads were cut into halves along the mid-sagittal plane. Specimens were immersed in methanol for $15 \mathrm{~min}$ at room temperature (RT) and then in $-20^{\circ} \mathrm{C}$ methanol for $45 \mathrm{~min}$. For rehydration, heads were sequentially incubated in $75 \%$ methanol, $50 \%$ methanol, and $25 \%$ methanol $(\mathrm{v} / \mathrm{v})$ in phosphate-buffered saline, $\mathrm{pH} 7.4$, supplemented with $0.05 \%(\mathrm{v} / \mathrm{v})$ Tween-20, $1 \%(\mathrm{v} / \mathrm{v})$ DMSO, $1 \mathrm{mM} \mathrm{CaCl}_{2}$, and $1 \mathrm{mM} \mathrm{MgCl}_{2}$ (PBT) for $15 \mathrm{~min}$ each at RT After a $15 \mathrm{~min}$ wash in PBT, unspecific binding of antibody was diminished by incubating the heads in PBT containing $5 \%$ horse serum (blocking solution) for 2 hr at RT. Heads were then incubated overnight on ice with the RCD-2 antibody diluted in blocking solution. Following five washes in PBT over a period of 6 $8 \mathrm{hr}$ on ice, heads were incubated with the biotinylated secondary antibody against mouse immunoglobulin supplied in the ABC Elite kit (Vector Laboratories) for 4-6 hr at RT. Heads were then again washed in $\mathrm{PBT}$ as above. $\mathrm{ABC}$ reagent was prepared according to the instructions supplied by the manufacturer and heads were incubated in the $\mathrm{ABC}$ reagent for $2 \mathrm{hr}$ at RT. After extensive washes in PBT and, finally, in phosphate-buffered saline (PBS) alone, heads were incubated for 1 hr at RT with substrate solution $[0.025 \%(\mathrm{w} / \mathrm{v})$ diaminobenzidine and $0.04 \%(\mathrm{w} / \mathrm{v}) \mathrm{NiCl}_{2}$ in PBS] at RT. To start the enzymatic reaction, peroxide was added to this solution at a final concentration of $0.01 \%$. After enough reaction product had accumulated, the reaction was stopped in water. Heads were viewed and photographed under a binocular microscope. Controls were processed in the same way but there was no incubation with first antibody.

Immunohistochemical procedures. Immunohistochemical procedures were described previously (Redies et al., 1992, 1993). Briefly, heads from E2-E8 embryos were fixed in $4 \%$ formaldehyde dissolved in Hanks' balanced salt solution supplemented with $1 \mathrm{mM} \mathrm{Ca}^{2+}$ and $1 \mathrm{~mm}$ $\mathrm{Mg}^{2+}$ (HBSS) for 1-2 hi, incubated in a graded series of sucrose solutions $[12 \%(\mathrm{w} / \mathrm{v}), 15 \%, 18 \%$ sucrose in HBSS] for $30-60 \mathrm{~min}$ each, embedded in Tissue Tek (Miles), and frozen in liquid nitrogen. Cryostat sections of $8 \mu \mathrm{m}$ thickness were mounted and dried on coated glass slides. After postfixation in $4 \%$ formaldehyde/HBSS and washing in Tris-buffered saline ( $\mathrm{pH}$ 7.6) supplemented with $1 \mathrm{mM} \mathrm{Ca}^{2+}\left(\mathrm{TBS} / \mathrm{Ca}^{2+}\right)$, membranes were permeabilized in methanol at $-20^{\circ} \mathrm{C}$ and washed again in TBS/Ca ${ }^{2+}$. Unspecific binding sites for antibody were blocked by $5 \%$ skim milk in $\mathrm{TBS} / \mathrm{Ca}^{2+}$ with $0.3 \%$ Triton $\mathrm{X}-100$ (blocking solution) for $20 \mathrm{~min}$. The sections were incubated with the first antibodies appropriately diluted in blocking solution for $1 \mathrm{hr}$. After washing in $\mathrm{TBS} / \mathrm{Ca}^{2+}$, secondary antibodies were applied to the sections for $30 \mathrm{~min}$.

For double-label immunohistochemistry with the antibodies RCD-2 and R5, sections were first immunostained with the antibody RCD-2 as described above but without methanol treatment. After postfixation in $2 \%$ formaldehyde $/ 0.025 \%$ glutaraldehyde in PBS at $4^{\circ} \mathrm{C}$ for $5 \mathrm{~min}$, sections were sequentially incubated with antibody R5, biotinylated secondary antibodies, and Fl'lC-labeled streptavidin.

Sections were counterstained in Hoechst 33258 (Sigma) for $5 \mathrm{~min}$ to visualize nuclei, washed in TBS, and embedded in a solution of $90 \%$ glycerol and $10 \%$ TBS/ $\mathrm{Ca}^{2+}$ supplemented by phenylenediamine to prevent photobleaching. Fluorescence was visualized with an epiffuorescence microscope (Zeiss Axioplan, Germany) to which a CC.D camera (Photometrix) was attached, or with a laser confocal microscope (BioRad). For analysis of double-labeled sections, computer-based image analysis systems were used to gencrate pseudocolored overlays of the fluorescence images in some instances. Adjacent sections were stained with thionin to detect Nissl substance for neuroanatomical orientation, as described previously (Redies et al., 1993).

The expression pattern of $\mathrm{R}$-cadherin was studied in detail by obtaining a complete series of 8 - $\mu$ m-thick consecutive sections through the diencephalon of E3, E3.5, E4, and E5 chicken embryos. Sections were spaced $80 \mu \mathrm{m}$ apart. For anatomical orientation, adjacent sections were immunostained with the antibody against neurofilament to demonstrate fiber tracts or they were Nissl stained. The R-cadherin-positive regions were marked on photographs of adjacent Nissl stains and then transferred onto scanning electron micrographs of the ventricular surface of brains at corresponding developmental stages.

Scanning electron micrographs were prepared using standard methods. Heads were cut along the mid-sagiltal plane and sequentially fixed in solutions containing $4 \%$ formaldehyde $/ 5 \%$ glutaraldehyde, $1 \% \mathrm{OsO}_{4}$, and $1 \%$ uranylacetate $(\mathrm{w} / \mathrm{v})$, respectively. After dehydration in graded ethanol, specimens were critical-point dried, shadowed with gold palladium, and viewed and photographed under a Hitachi S800 scanning electron microscope. The alignment of the serial Nissl stains and the scanning electron micrographs was based on prominent anatomical landmarks, taking into account shrinking artifacts $(10-20 \%)$ due to fixation.

Bromodeoxyuridine (BrdU) experiment. To demonstrate $\mathrm{Brd} \mathbf{U}$ incorporation by proliferating cells in $S$ phase, shell-less cultures of chicken embryos werc obtained as described by Auerbach ct al. (1974) and modified by Thanos and Bonhoeffer (1983). Briefly, the entire content of E3 eggs was transferred to humidified, $20 \times 100 \mathrm{~mm}$ petri dishes (Greiner, Germany) and incubated for $1 \mathrm{~d}$ at $37^{\circ} \mathrm{C}$. BrdU $(2-5 \mu l$ of a $50 \mathrm{~mm}$ solution in HBSS) (Sigma, Germany) was injected into the tectal ventricle of the embryos. The embryos were fixed $1 \mathrm{hr}$ later. Sections obtained as described above were double-immunostained with antibodies against R-cadherin and BrdU. After R-cadherin immunostaining (see Immunohistochemical procedures, above), the sections were postfixed in $4 \%$ formaldehyde/HBSS at $4^{\circ} \mathrm{C}$ for $30 \mathrm{~min}$, washed in TBS, and incubated in $2 \mathrm{~N} \mathrm{HCl}$ at $37^{\circ} \mathrm{C}$ for $30 \mathrm{~min}$ to denature the DNA. After the sections were washed in $0.1 \mathrm{M}$ tetraborate buffer ( $\mathrm{pH} 8.5$ ) (TBB), the unspecific antibody binding sites were blocked in $5 \%$ skim milk/TBB supplemented with $0.3 \%$ Triton X-100. The sections were

for R-cadherin. R-cadherin mRNA expression was visualized with peroxidase-labeled antibodies against digoxigenin. The approximate level at which these sections were obtained is indicated by the two opposing long arrows in Figure $2 A$. In $B$ and $C$, note the distinct areas of R-cadherin expression in the ventricular zone and in the mantle zone. $A$ and $B$ show the same section, while $C$ shows an adjacent section. $C$, caudal; $R 2-R 6$, R-cadherin-positive regions corresponding to the stripes and patches shown in Figure $2 ; r$, rostral; sa, anterior intracephalic sulcus; si, lateral infundibular sulcus (Kuhlenbeck, 1937). Scale bar, $0.1 \mathrm{~mm}$. 
then incubated at $37^{\circ} \mathrm{C}$ for $1 \mathrm{hr}$ with the $\mathrm{BrdU}$ antibody appropriately diluted in the blocking solution. After washing in TBS, the slides were incubated with secondary antibody at RT for $30 \mathrm{~min}$, washed in TBS, and embedded and viewed as described above.

Acetylcholinesterase (AChE) histochemistry. To visualize postmitotic neuroblasts, AChE activity was detected by a modified KarnovskyRoots technique (Karnovsky and Roots, 1964; Layer, 1983). R-cadherin immunostaining and AChE histochemistry were combined on the same sections. After immunostaining for R-cadherin (see above), the sections were postfixed in $4 \%$ formaldehyde/HBSS for $30 \mathrm{~min}$ at $4{ }^{\circ} \mathrm{C}$. Following sequential washing in TBS and $0.1 \mathrm{M}$ Tris maleate buffer $(\mathrm{pH} \mathrm{6.0)}$, the sections were incubated for $2-4 \mathrm{hr}$ at $37^{\circ} \mathrm{C}$ in a solution of $2.56 \mathrm{~mm}$ acetylthiocholine, $5 \mathrm{~mm}$ sodium citrate, $3 \mathrm{~mm} \mathrm{CuSO}_{4}, 0.5 \mathrm{~mm}$ $\mathrm{K}_{3} \mathrm{Fe}(\mathrm{CN})_{6}$, and $0.1 \mathrm{~mm}$ tetraisopropylpyrophosphoramide (iso-OMPA) (Serva, Germany) in 0.1 M Tris maleate buffer ( $\mathrm{pH} \mathrm{6.0)}$ to inhibit butyrylcholinesterase. After washing in TBS, the slides were embedded as described above.

In situ hybridization. Procedures were performed as described by Redies et al. (1993). The pBluescript (Stratagene) DNA vectors pRcad and Z10T6/BS, which were used as templates to produce the RNA probes, were kindly provided by $M$. Takeichi. The pRcad and Z10T6/BS vectors contain the full-length $\mathrm{cDNA}$ for chicken $\mathrm{R}$-cadherin and N-cadherin, respectively. After linearization of the template DNAs with the appropriate restriction enzymes, the sense and antisense digoxigeninlabeled RNA probes were synthesized by T3 and T7 polymerase using a commercially available kit (Boehringer Mannheim, Germany). The labeled full-length RNAs were alkaline hydrolyzed into $100-300$ bp fragments.

Complete series of 8-pm-thick consecutive transverse cryostat sections through the diencephalon of E3.5, E4, and E5 chicken embryos were obtained and treated as described before (Redies et al., 1993). Sections were spaced $80 \mu \mathrm{m}$ apart. For permeabilization, sections were treated with proteinase $\mathrm{K}$ and, to saturate unspecific RNA binding sites, with acetic anhydrate. The sections were hybridized with sense and antisense digoxigenin-labeled RNA probes overnight at $50^{\circ} \mathrm{C}$. The sections were then washed in $5 \times \mathrm{SSC}$ at $55^{\circ} \mathrm{C}$ for $10 \mathrm{~min}$ and in $50 \%$ formamide $/ 2 \times \mathrm{SSC}$ at $55^{\circ} \mathrm{C}$ for $1 \mathrm{hr}$. After digestion of single-stranded RNA by RNase A treatment, the sections were washed in $50 \%$ formamide $/ 2 \times \mathrm{SSC}$ at $55^{\circ} \mathrm{C}$ for $40 \mathrm{~min}$, in $2 \times \mathrm{SSC}$ at $55^{\circ} \mathrm{C}$ for $30 \mathrm{~min}$, and in $0.1 \times$ SSC at RT for $30 \mathrm{~min}$. Digoxigenin was detected immunologically with anti-digoxigenin alkaline phosphatase-conjugated Fab fragments and alkaline phosphatase was reacted with substrate following the instructions supplied by the manufacturer of the kit (Roehringer Mannheim, Germany). Sections were dehydrated in an ascending ethanol series $(70 \%, 95 \%, 100 \%)$, defattened in xylenes, embedded in Entellan (Merck, Germany), and viewed under a transmission light micro scope (Zeiss Axioplan, Germany).

\section{Results}

Expression of $R$-cadherin in the diencephalon of an $E 5$ chicken embryo

Figure 1 shows representative immunostaining and in situ hybridization results for a transverse section through the hypo thalamus of a chicken of $5 \mathrm{~d}$ incubation (E5). Expression of R-cadherin mRNA and protein is restricted to several areas of the ventricular and mantle zone. These areas are distributed throughout the brain. We therefore studied the overall expression pattern in more detail by whole-mount immunostaining. Figure 2 shows results for an E5 brain cut in half in the mid-sagittal plane and viewed from the ventricular side. The entire brain (Fig. 2A) as well as enlargements of individual brain regions
(Fig. 2B-E) are shown. In a caudal-to-rostral' sequence, the following regions of $\mathrm{R}$-cadherin expression can be seen. In the isthmic region (is) at or close to the transition between mes- and metencephalon, there is a stripe of $\mathrm{R}$-cadherin expression (area R10) (Fig. 2A,E). The tectum (tect) contains R-cadherin-positive cells that are dispersed throughout its deeper layers, in particular at the base of the tectum (area R9 in Fig. 2A). In the pretectal area ( $p t)$, scattered R-cadherin-positive cells are observed at a later developmental stage (E8) (data not shown). In the dorsocaudal part of the dorsal thalamus $(\mathrm{dt})$, a triangle of $\mathrm{R}$-cadherin expression is seen (area R8 in Fig. $2 A, B$ ). The epithalamus, which is partially occluded in Figure $1 A$, also expresses R-cadherin. The ventral thalamus (vt) expresses high amounts of $\mathrm{R}$-cadherin in its entirety (area R7) (Fig. 2A,B). This area of expression is contiguous with another stripe (area R3) extending from the thalamic/hypothalamic border ventrally toward the optic stalk, which is indicated by an asterisk in Figure 2, $A$ and $C$. Stripe R3 comprises the anterior hypothalamic (ah) and posterior preoptic regions (pop) of the hypothalamus (Fig. $2 A, C$ ) and extends into the telencephalon (tel) (Fig. 2D). The entire stripe R3 has a sharp rostral boundary of expression. Caudally, expression gradually diminishes in the hypothalamus (ht). In the ventral thalamus, the caudal boundary of expression of area R7 is relatively sharp and coincides with a morphologically distinct structure, the zona limitans intrathalamica (arrowheads in Fig. $2 A, B$ ) (see helow)

Besides area R3, there are several other areas of R-cadherin expression in the hypothalamus (Fig. 2C). Like area R3, these areas are elongated. Areas R4 and R5 have an orientation roughly orthogonal to the zona limitans while the orientation of area R6 is similar to that of the zona limitans. Area R4 is relatively thin and its dorsal part merges with area R3. Area R5 forms part of the hypothalamic cell cord (hcc) (Kuhlenbeck, 1937). Area R6 comprises the posterior entopeduncular (pep) area of the hypothalamus (compare with the transverse section displayed in Fig. $1 B$ ). This stripe is partially contiguous with area R5. Rostral to area R3, two additional patches of expression (areas R1 and $\mathrm{R} 2$ ) are situated at the transition between diencephalon and telencephalon.

\section{Differential expression of $R$-cadherin in the ependymal, ventricular, and mantle zones of the E3-E5 diencephalon}

To analyze the onset of R-cadherin expression in the different layers of the diencephalic wall, we obtained several series of consecutive, immunostained sections through the chicken diencephalon at different stages of development (E2-E5) (see Fig.

\footnotetext{
${ }^{1}$ For general anatomical orientation, the following terminology is used to define the axes of the E3-E7 chicken brain: rostral-caudal, from the anterior pole of the telencephalon to the posterior pole of the tectum; ventral-dorsal, from the optic stalk to the epiphysis. These terms do not refer to the longitudinal axis of the vertebrate brain as defined by Kuhlenbeck (1973) or by Puelles and Rubenstein (1993).
}

\footnotetext{
Figure 2. Whole-mount preparation of an E5 chicken brain immunostained for R-cadherin and viewed from the ventricular surface. Dark purple reaction product indicates R-cadherin expression. Panels show an overview of the preparation $(A)$, the thalamic area $(B)$, the hypothalamic area $(C)$, the transition between di- and telencephalon viewed from a rostral direction $(D)$, and the transition between mes- and metencephalon $(E)$. The arrowheads in $A$ and $B$ point to the zona limitans intrathalamica. The asterisks in $A$ and $C$ indicate the position of the optic stalk. The two opposing long arrows in $A$ indicate the approximate level at which the transverse sections shown in Figure 1 were cut. $a h$, anterior hypothalamus; $d t$, dorsal thalamus; $h b$, hindbrain; $h c c$, hypothalamic cell cord; $h t$. hypothalamus; $i s$, isthmic area; pep. posterior entopeduncular area; $p o p$, posterior preoptic area; $p t$, pretectal area; $R l-R I O$, R-cadherin-positive regions; $t e c t$, tectum; $t e l$, telencephalon; $v t$, ventral thalamus. Scale bars: $A, 0.5$ mm; $B-E$, 0.2 $\mathrm{mm}$.
} 

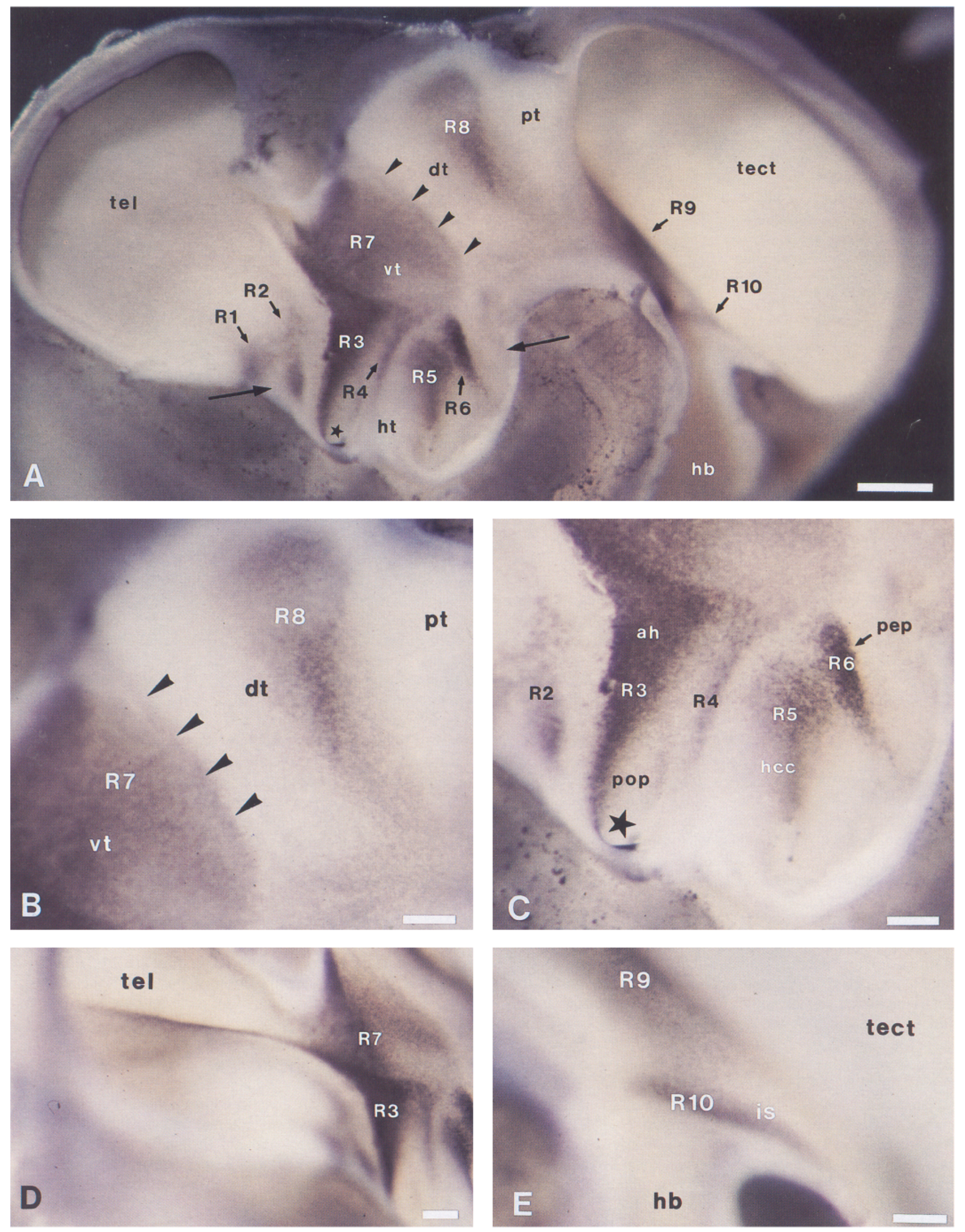
Table 1. Immunostaining results for R-cadherin in the diencephalon of the embryonic chicken brain of 3-5 d incubation (E3-E5) (stages 19-27)

\begin{tabular}{|c|c|c|c|c|c|}
\hline Region & Anatomical location & $\begin{array}{l}\text { Stage } 19 \\
(\mathrm{E} 3)\end{array}$ & $\begin{array}{l}\text { Stage } 21 \\
\text { (E3.5) }\end{array}$ & $\begin{array}{l}\text { Stage } 24 \\
(\mathrm{E} 4)\end{array}$ & $\begin{array}{l}\text { Stage } 27 \\
\text { (E5) }\end{array}$ \\
\hline R1 & $\begin{array}{l}\text { Transition between diencephalon } \\
\text { and telencephalon }\end{array}$ & - & M & $\mathrm{e}, \mathrm{M}$ & $\mathrm{e}, \mathrm{V}, \mathrm{M}$ \\
\hline $\mathrm{R} 2$ & Anterior preoptic rcgion & - & - & $\mathrm{E}, \mathrm{V}$ & $\mathrm{e}, \mathrm{V}, \mathrm{M}$ \\
\hline R3 & Posterior preoptic region & - & $\mathrm{e}$ & $\mathrm{E}, \mathrm{V}$ & $\mathrm{E}, \mathrm{V}, \mathrm{M}$ \\
\hline $\mathrm{R} 4$ & Anterior hypothalamus & - & - & $\mathrm{M}$ & $\mathrm{M}$ \\
\hline R5 & $\begin{array}{l}\text { Inferior hypothalamus } \\
\text { (hypothalamic cell cord) }\end{array}$ & M & $\mathrm{e}, \mathrm{M}$ & $\mathrm{e}, \mathrm{V}, \mathrm{M}$ & $\mathrm{e}, \mathrm{V}, \mathrm{M}$ \\
\hline R6 & $\begin{array}{l}\text { Superior hypothalamus } \\
\text { (posterior entopeduncular area) }\end{array}$ & - & - & $\mathrm{V}$ & $\mathrm{E}, \mathrm{V}, \mathrm{M}$ \\
\hline R7 & Ventral thalamus & - & - & $\mathrm{E}, \mathrm{M}$ & $\mathrm{E}, \mathrm{V}, \mathrm{M}$ \\
\hline R8 & Dorsal thalamus & - & - & $\mathrm{E}$ & $\mathrm{E}, \mathrm{V}, \mathrm{M}$ \\
\hline
\end{tabular}

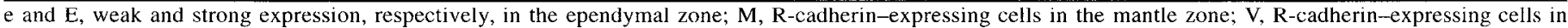
the ventricular zone.

$1 B$ for an example). For those stages that clearly showed R-cadherin-positive regions (E3.5-E5), the immunostaining results were transferred onto scanning electron microscopic images of the diencephalic ventricular surface at corresponding stages of development (data not shown). The time of appearance and the location of the different patches of R-cadherin expression in the diencephalon between E3 and E5 are summarized in Table 1.

Before E2.5, there is no or very faint expression of R-cadherin only in the ependymal zone of the forebrain. At E3-E3.5, weak to moderate expression of $\mathrm{R}$-cadherin is seen in relatively large and diffuse areas of the ependymal and ventricular zone and in two narrow stripes consisting of cells in the mantle zone. The different R-cadherin-positive areas gradually appear between E3 and E5. Between E5 and E8, R-cadherin expression in some of the stripes diminishes or even disappears. In other regions, expression persists, especially in newly formed nuclei (Redies et al., 1993; Arndt and Redies, unpublished observations). In general, R-cadherin-positive cells appear in the mantle zone and expression persists for at least a few days in almost all regions. In some regions, $\mathrm{R}$-cadherin is also expressed in the ependymal and ventricular zones. This ventricular expression either precedes or overlaps with the expression in the mantle zone. Not listed are regions in which $\mathrm{R}$-cadherin expression occurs after $\mathrm{E} 5$, for example, the pretectal area.

\section{Boundaries of $R$-cadherin expression}

Some R-cadherin-positive areas are delincated by sharp boundaries of expression (see, e.g., areas R3, R7, and R8 in Fig. 2). In some cases, these expression boundaries coincide with anatomical landmarks. For example, R-cadherin expression in the ventral thalamus stops at the zona limitans intrathalamica (arrowheads in Fig. 2A, $B$; $\mathrm{zl}$ in Fig. $3 A-D$ ), which represents the border between the ventral and dorsal thalamus (vt and $\mathrm{dt}$, respectively, in Figs. $2 A, B ; 3 A-D$ ). The zona limitans is a cellsparse area and contains the primordial mammillothalamic tract. It forms a visible bulge on the ventricular surface of E4 and E5 embryos. Figure $3 A$ shows that, at E4, the ventricular zone expresses R-cadherin at the position of the zona limitans intrathalamica. Moreover, R-cadherin-expressing cells in the mantle layer are present in the ventral thalamus up to the zona limitans intrathalamica but are absent on the other side of this boundary (in the dorsal thalamus). At a later stage (E6), the decrease in
R-cadherin expression at the zona limitans intrathalamica is even more striking (Fig. 3C). It is noteworthy that, at this stage, the boundary of R-cadherin expression does not coincide with the depth of the medial diencephalic sulcus (Kuhlenbeck, 1937) (sm in Fig. 3C) but slightly extends beyond it. The decrease in $\mathrm{R}$-cadherin expression at the border between the dorsal thalamus and the pretectal area is also prominent at E5 ( $\mathrm{dt}$ and pt in Figs. $2 A, B ; 3 E$ ) and E6 (data not shown), although this decrease is not as sharp as that between the ventral and the dorsal thalamus.

\section{$R$-cadherin expression in the mid-hypothalamic region}

To determine which type of cell expresses R-cadherin and to study the origin and fate of the R-cadherin-expressing cells, we concentrated on the development of a particular region of the hypothalamus, the mid-hypothalamic (tuberal) region (Kuenzel and van Tienhoven, 1982). Figure 4 shows R-cadherin expression in this region during early development of the ventricular wall from E3 to E5. The sections were cut transversely through the hypothalamic cell cord (hcc) and the posterior entopeduncular area (pep) (Kuhlenbeck, 1937). The nuclear stains (right panels) reveal the features characteristic for the development of this structure: the ventricular zone consists of densely packed (proliferating) cells and remains relatively constant in thickness from E3 to E5. In contrast, at E3, the mantle zone is composed of only a few cells scattered between the ventricular zone and the pial surface of the neural tube. The mantle zone, which is characterized by more sparsely distributed nuclei, gradually increases in thickness during development (Fig. $4 B, D, F, H, K$ ). This increase is due to the accumulation of postmitotic neuroblasts having migrated from the ventricular zone into the mantle zone (Sauer, 1935; Fujita, 1964).

Ventricular zone. In the ventricular zone of the mid-hypothalamic region shown in Figure 4, R-cadherin is expressed by bipolar cells at all developmental stages (E3-E5). These R-cadherin-expressing cells are first seen approximately at the beginning of mantle zone formation (E3) and they are most prominent and numerous between E4 and E5. In later development, their number and staining intensity decrease. For further investigation of this cell type, we focused on developmental stage E4-4.5. At this stage, less than about $5 \%$ of all cells in the ventricular zone express R-cadherin (Fig. 5A). The distribution of the cell bodies of these cells shows a steady increase from the ventricular lining 

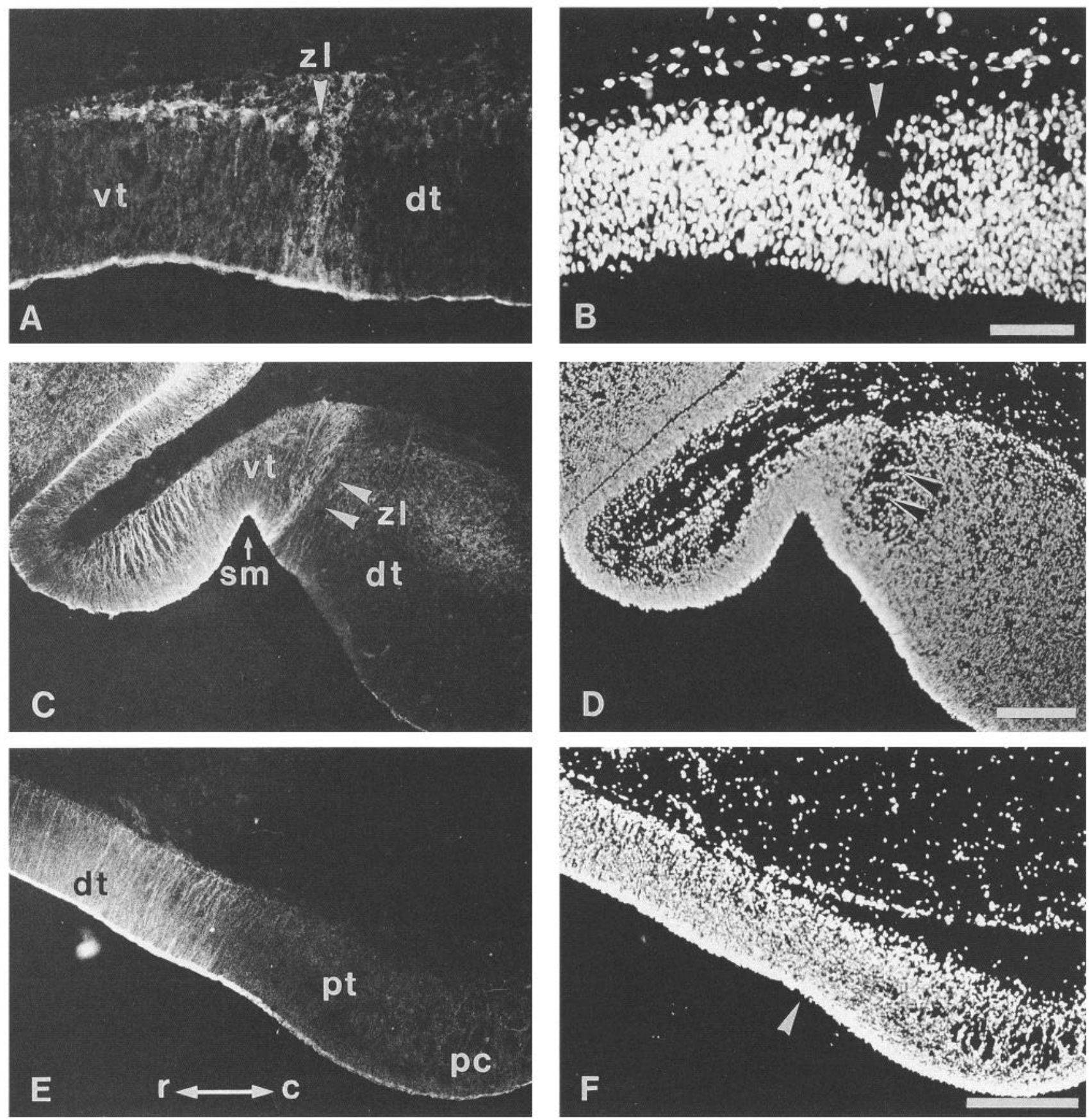

Figure 3. Transverse sections through the diencephalon of an $\mathrm{E} 4(A, B)$, an $\mathrm{E} 6(C, D)$, and an E5 chicken embryo $(E, F)$. Immunostains for $\mathrm{R}$-cadherin $(A, C, E)$ and nuclear stains $(B, D, F)$ are from the same sections, respectively. The arrowheads in $A-D$ point to the zona limitans intrathalamica. The arrowhead in $F$ marks the dorsal thalamic sulcus, which lies slightly caudal of the boundary between the dorsal thalamic and the pretectal neuromere (Rendahl, 1924; Puelles and Rubenstein, 1993). $c$, caudal; $d t$, dorsal thalamus; $p c$, posterior commissure; $p t$, pretectal area; $r$, rostral; $s m$, medial diencephalic sulcus; $v t$, ventral thalamus; $z l$, zona limitans intrathalamica. Scale bars, $0.2 \mathrm{~mm}(B$ for $A$ and $B ; D$ for $C$ and $D ; F$ for $E$ and $F$ ).

toward the mantle zone (see Fig. 7). Not only the cell bodies but also their processes express R-cadherin. Usually, one process of each cell extends to the ventricular surface, where it forms an end-foot in the ependymal lining, while the other process reaches the mantle zone (see, e.g., cells in area R5 in Fig. $1 B$, Figs. $5 A, 8 A$ ).

To determine whether the bipolar R-cadherin-expressing cells are radial glia, double immunostaining with antibodies against a radial glia marker (R5) (Dräger et al., 1984; Vanselow et al.,
1989) and R-cadherin was performed. Figures $5 B$ and $6, A$ and $B$, demonstrate that the R-cadherin-expressing cells do not stain with the R5 antibody. Interestingly, the processes of the radial glia and of the R-cadherin-expressing cells were occasionally seen to be closely aligned with each other (small arrows in Fig. $5 C)$.

In another region, the posterior preoptic area (pop) (area R3 in Figs. $1 B, 2 C$ ), the R-cadherin staining pattern in the ventricular zone is more dense and single cells expressing this molecule 

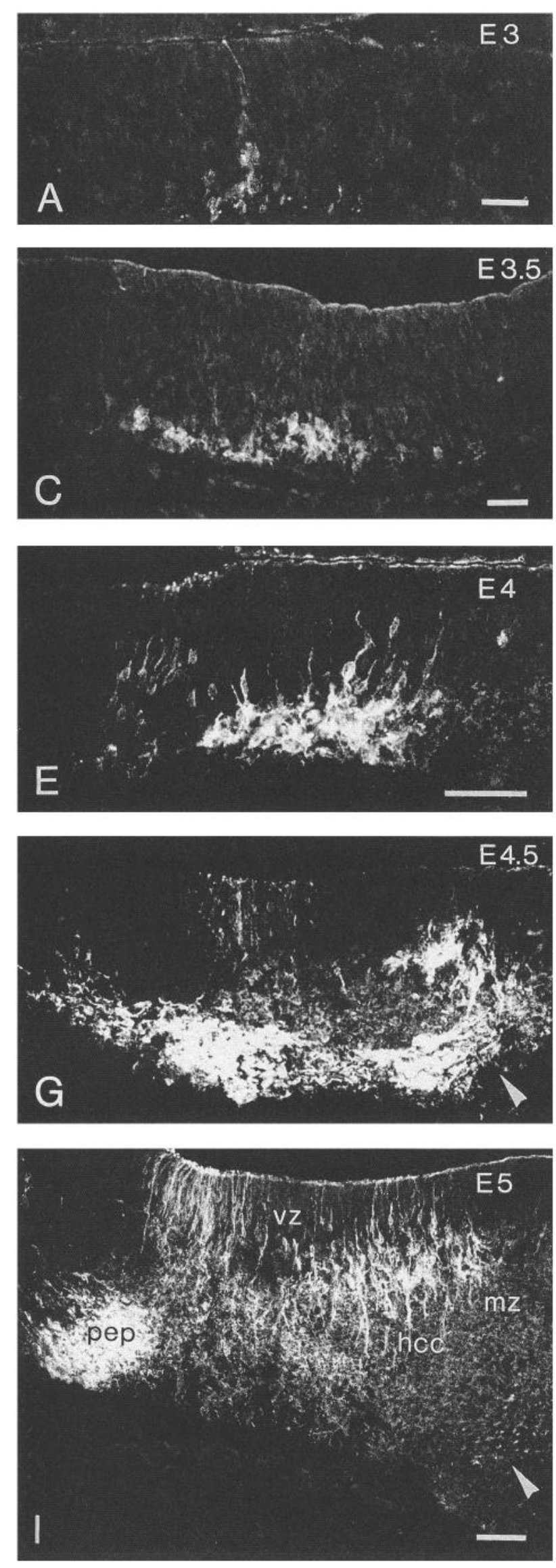
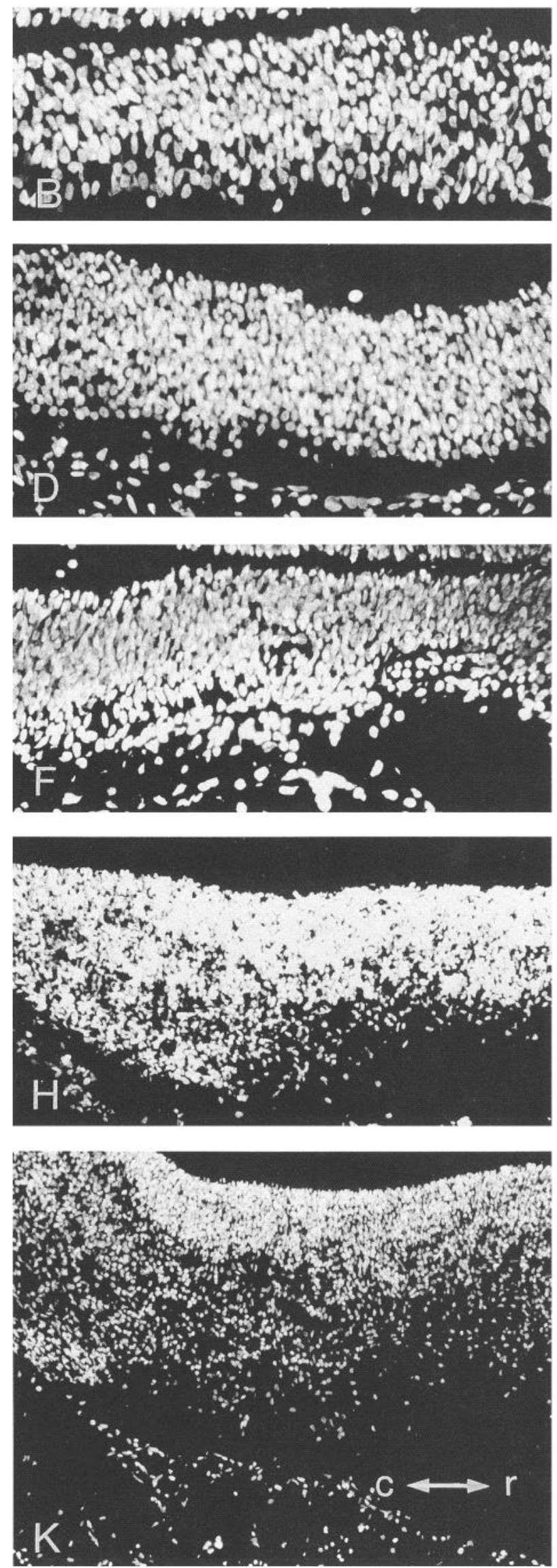
cannot be discerned. In this arca, most R-cadhcrin-cxpressing processes coexpress R5 (data not shown). These R-cadherinexpressing cells have processes that extend from the ependymal layer to the pial surface of the brain, and they most likely represent radial glia.

We next injected bromodeoxyuridine (BrdU) into the ventricular system of E4 embryos to mark cells in the S phase, that is, proliferating cells. Double-label immunohistochemistry with antibodies against BrdU and R-cadherin showed that, in the ventricular zone of areas R5 and R6, only very few R-cadherinexpressing cells incorporate BrdU (Fig. 5E). A quantitative anal$y$ sis of several brains showed that, of the R-cadherin-expressing cells, only $1.7 \%(2.0 \mathrm{SD}, n=5)$ incorporated BrdU during the $1 \mathrm{hr}$ before fixation, while, of all cells in the ventricular zone, $15.5 \%$ (1.6 SD, $n=4$ ) incorporated BrdU (arrows in Fig. $5 E$ ).

As a marker for postmitotic neuroblasts (Miki and Mizoguti, 1982; Mizoguti and Miki, 1985; Layer and Sporns, 1987), acetylcholinesterase (AChE) activity was histochemically visualized by a modified Karnovsky-Roots method (Karnovsky and Roots, 1964; Layer, 1983). Sections were double-stained for AChE activity and R-cadherin expression. In most regions, AChE activity is restricted to the mantle zone. However, in regions where R-cadherin-expressing cells are found in the ventricular zone, AChE activity extends into this zone (arrowheads in Fig. 8A,B). Most of the R-cadherin-expressing cells in the ventricular zone show AChF activity (arrowheads in Fig. 8C,D). AChE-positive cells are also found in adjacent ventricular regions where $\mathrm{R}$-cadherin expression is absent.

To examine whether the R-cadherin-positive cells express another marker for postmitotic neuroblasts, the Ng-CAM/8D9/G4 protein (Grumet and Edelman, 1984; Thiery et al., 1985; Rathjen et al., 1987; Weikert et al., 1990; Grumet, 1992; Lemmon and McLoon, 1986), double-label immunohistochemistry was carried out. Results showed that most, if not all, R-cadherin-expressing cells in the ventricular zone coexpress G4 (arrowheads in Figs. $5 D, 6 C, D)$. However, there are also cells in the ventricular zone that express G4 but not R-cadherin (arrows in Figs. $5 D, 6 C, D$ ). These cells have a morphology similar to the R-cadherin-expressing cells.

Mantle zone. In the mantle zone of areas R5 and R6, cells expressing R-cadherin are found (Fig. 4, left panels). While, at E3, only a few R-cadherin-expressing cells can be seen (Fig. $4 A$ ), their number increases as the mantle zone becomes greater in thickness from $\mathrm{E} 3$ to $\mathrm{E} 5$ (Fig. $4 C, E, G, I$ ). Before E4.5, the $\mathrm{R}$-cadherin-expressing cells in the mantle zone form one contiguous mass. Starting at E4.5, they organize into two clusters with the more rostral one lying in the inferior hypothalamus (hypothalamic cell cord) (hcc in Figs. $2 C, 4 I$ ) and the more caudal one in the superior hypothalamus (posterior entopeduncular area) (pep in Figs. 2C, 4I) (Kuhlenbeck, 1937).2 These

\footnotetext{
$\overline{2}$ The more rostral cluster of R-cadherin-expressing cells (R5 in Figs. $1 B, 2 A, C$ ) appears to give rise to the ventromedial hypothalamic nucleus (Kuenzel and van Tienhoven, 1982); the more caudal cluster (R6 in Fig. 2A,C) most likely represents the primordial nucleus of the ansa lenticularis (Karten and Dubbeldam, 1973).
}

$\mathrm{R}$-cadherin-positive regions are surrounded by $\mathrm{R}$-cadherin-negative regions (Fig. 4I). In some areas, R-cadherin-expressing neurite fascicles can be seen in areas devoid of nuclei (arrowheads in Fig. 4G,I).

\section{Emergence of $N$-cadherin-positive regions adjacent to $R$-cadherin-positive regions in the mantle zone}

At later developmental stages (around E11), N-cadherin-expressing nuclei are also present in the chicken hypothalamus (Redies et al., 1993). We therefore compared the expression of $\mathrm{R}$-cadherin with that of $\mathrm{N}$-cadherin in this area. Since $\mathrm{N}$-cadherin protein is rather ubiquitously expressed by most cells and their processes extend throughout the diencephalic wall, we visualized cell bodies expressing $\mathrm{N}$-cadherin in the mantle zone by in situ hybridization with digoxigenin-labeled RNA probes. On adjacent sections, R-cadherin mRNA was detected.

Results show that, at the beginning of mantle zone formation (E3.5), R-cadherin-positive and N-cadherin-positive regions (arrows in Fig. 9A,B) largely overlap. At FA, these regions overlap only partially, with the R-cadherin-positive region (arrowhead in Fig. 9C,D) being located more rostrally and the $\mathrm{N}$-cadherin-positive region (arrow in Fig. 9C,D) more caudally. At E5, two R-cadherin-positive and two N-cadherin-positive regions have emerged. In the posterior entopeduncular area, the $\mathrm{R}$-cadherin-positive region (arrowheads in Fig. 9E,F) lies caudally and directly adjacent to the $\mathrm{N}$-cadherin-positive region (arrows in Fig. 9E,F) while, in the hypothalamic cell cord (hcc), the $\mathrm{R}$ - and $\mathrm{N}$-cadherin-positive regions form part of two adjacent layers of the mantle zone. ${ }^{3}$

\section{Discussion}

During development, the vertebrate CNS undergoes a transformation from a relatively uniform neuroepithelial structure into a highly complex but ordered tissue architecture comprising functionally specialized regions connected by fiber tracts. In this work, we studied the expression of the cell-cell adhesion molecule R-cadherin during the early stages of this transformation during which brain nuclei are formed by neuroblasts born in the different morphogenetic domains ("neuromeres") of the forebrain neuroepithelium.

Cadherins are glycoproteins that mediate cell-cell adhesion by a calcium-dependent mechanism in a variety of organs (Takeichi, 1988, 1991; Ranscht, 1991). Molecular and in vitro investigations have shown that cadherins have the following properties that are potentially important for the developmental process outlined above. (1) Cadherins mediate the aggregation of cells by a homophilic adhesion mechanism; that is, cells expressing the same cadherin selectively adhere to each other ( $\mathrm{Na}-$ gafuchi et al., 1987; Miyatani et al., 1989). (2) At least a dozen different cadherins are expressed in the developing vertebrate brain (Takeichi et al., 1990; Ranscht, 1991; Suzuki et al., 1991; Sano et al., 1993). (3) Cells expressing different cadherins seg-

\footnotetext{
${ }^{3}$ The two clusters of $\mathrm{N}$-cadherin-expressing cells appear to give rise to parts of the lateral hypothalamic nucleus (Kuenzel and van Tienhoven, 1982).
}

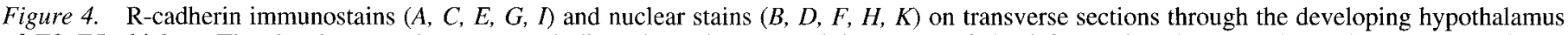

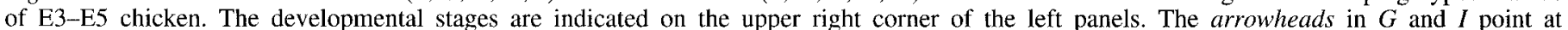

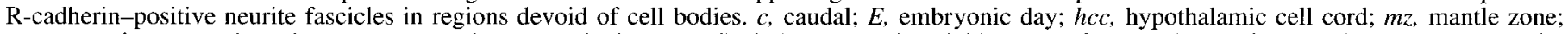

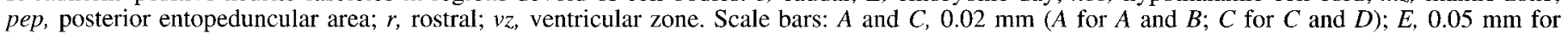
$E$ and $F ; I, 0.15 \mathrm{~mm}$ for $G-K$. 

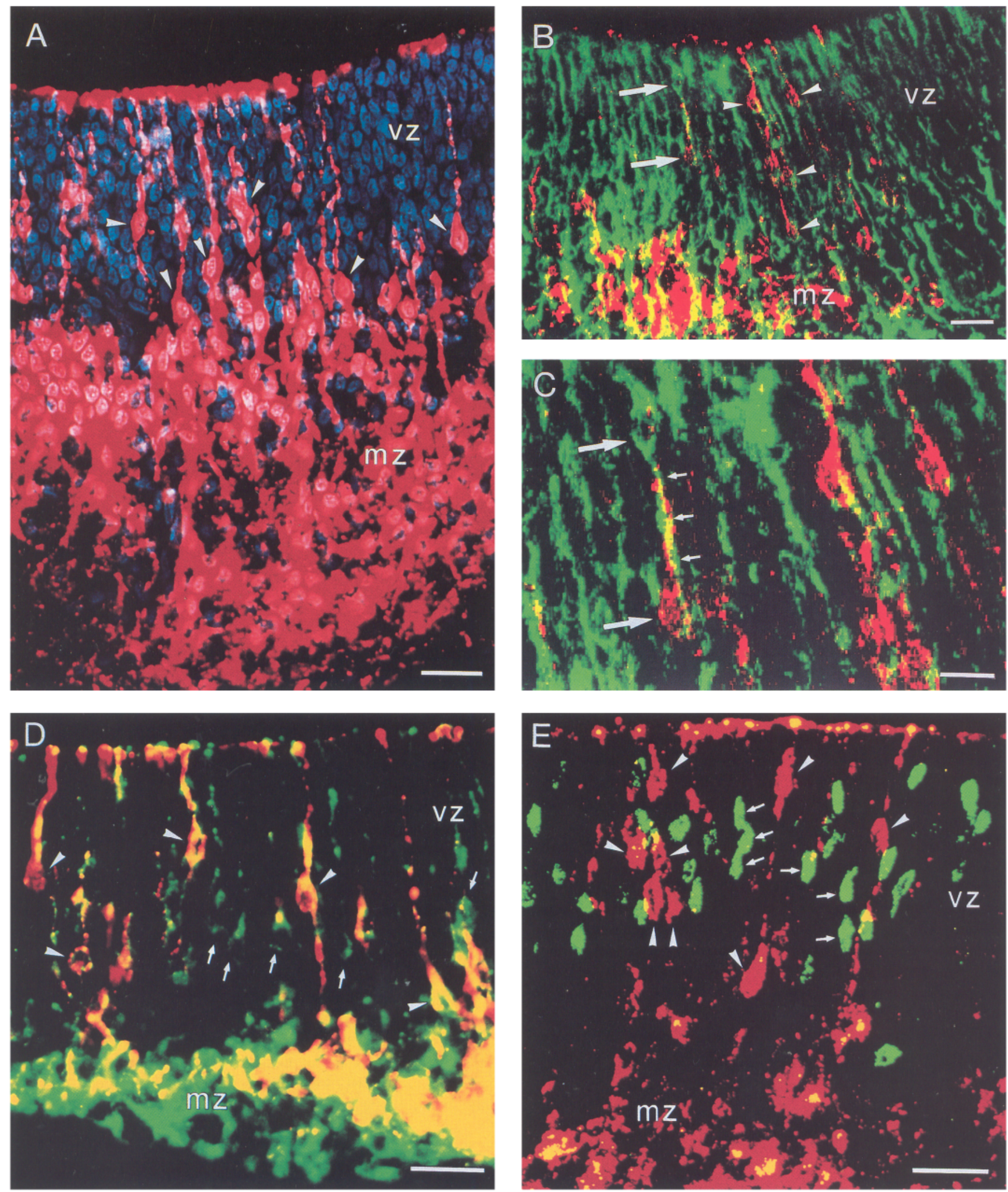

Figure 5. Characterization of the R-cadherin-expressing cells in the ventricular zone of the E4 chicken embryo. All panels show pseudocolorcoded double-label immunostaining on the same sections. The arrowheads in all panels point at cell bodies of R-cadherin-expressing cells. A, Immunostain against R-cadherin (red) and nuclear stain (blue). $B$ and $C$, Immunostain against R-cadherin (red) and R5, a marker for radial glia (green). Gray-scaled micrographs of the original pair of immunostaining results are shown in Figure 6, $A$ and $B$. $C$ shows a detail of $B$ at higher magnification. The two large arrows in $B$ and $C$ mark the same pair of cells. The small arrows in $C$ point at two closely aligned processes of a radial glial cell and an R-cadherin-expressing cell, respectively. D, Immunostain against R-cadherin (red) and Ng-CAM/8D9/G4, a marker for 

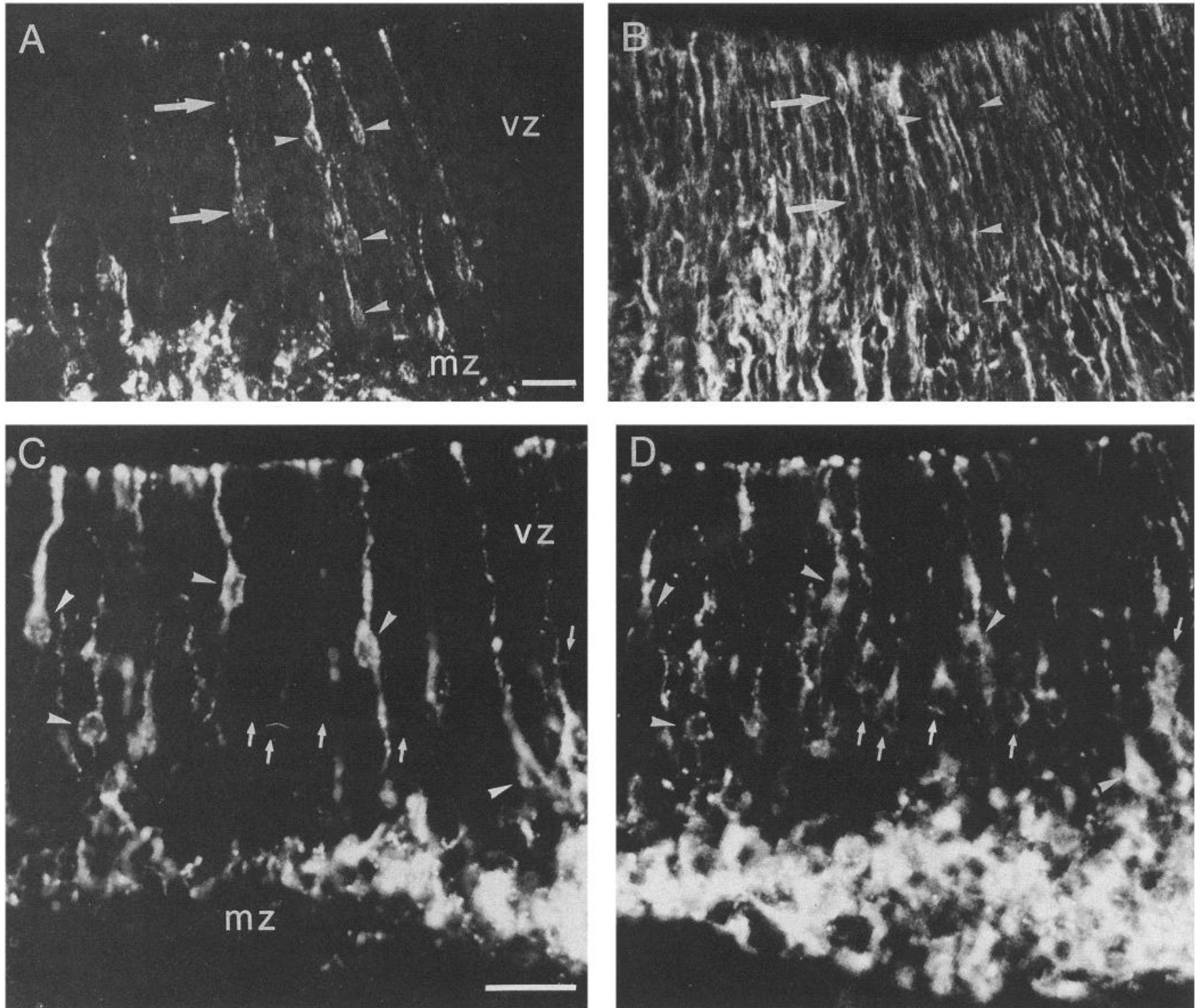

Figure 6. Characterization of the R-cadherin-expressing cells in the ventricular zone of the E4 chicken embryo. This figure shows the original pairs of gray-scaled micrographs displayed as pseudocolored overlays in Figure $5, B$ and $D$. $A$ and $B$, and $C$ and $D$ represent double-label immunostains of the same sections, respectively. The arrowheads in all panels point at cell bodies of R-cadherin-expressing cells. $A$ and $B$ Immunostain against R-cadherin $(A)$ and R5, a marker for radial glia $(B)$. The two arrows mark the same pair of cells as those marked in Figure $5, B$ and $C$. $C$ and $D$, Immunostain against R-cadherin $(C)$ and $\mathrm{Ng}$-CAM/8D9/G4, a marker for neuroblasts $(D)$ ). The arrows mark cell bodies of $\mathrm{Ng}$-CAM/8D9/G4-expressing cells that do not express R-cadherin. $m z$, mantle zone; $v z$, ventricular zone. Scale bars, $0.02 \mathrm{~mm}(A$ for $A$ and $B$; $C$ for $C$ and $D$ ).

regate from each other to form separate aggregates (Nose et al., 1988; Miyatani et al., 1989; Inuzuka et al., 1991).

\section{$R$-cadherin expression in forebrain neuromeres of the chicken embryo}

$\mathrm{R}$-cadherin is expressed in several stripes and patches in the embryonic chicken brain (Figs. 1, 2; Table 1). The anatomical location of the R-cadherin-positive regions can be related, at least in part, to the neuromeric organization of the vertebrate forebrain (von Baer, 1828; Palmgren, 1921; Rendahl, 1924; Bergquist and Källén, 1953a,b, 1954; Keyser, 1972; Kuhlenbeck, 1973; Puelles et al., 1987; Bulfone et al., 1993; Figdor and Stern, 1993; Puelles and Rubenstein, 1993). For example, R-cadherin is expressed in the entire ventral thalamic (vt) neuromere (area $\mathrm{R} 7$ in Fig. 2A,B) with a sharp boundary of expression at the zona limitans intrathalamica (zl), which forms the boundary to the adjacent neuromere, the dorsal thalamus (dt) (Figs. $2 A, B$; $3 A, C)$. In the dorsal thalamus, $\mathrm{R}$-cadherin is expressed in the $\leftarrow$

neuroblasts (green). Gray-scaled micrographs of the original pair of immunostaining results are shown in Figure $6, C$ and $D$. Note that the R-cadherin-expressing cells coexpress Ng-CAM/8D9/G4. The arrows mark cell bodies of Ng-CAM/8D9/G4-expressing cells that do not express $\mathrm{R}$-cadherin. E, Immunostain against R-cadherin (red) and BrdU (green). The arrows point at nuclei that have incorporated BrdU. Note that the R-cadherin-expressing cells are BrdU negative. $m z$, mantle zone; $v z$, ventricular zone. Scale bars: $A, B, D$, and $E, 0.02 \mathrm{~mm} ; C, 0.01 \mathrm{~mm}$. 


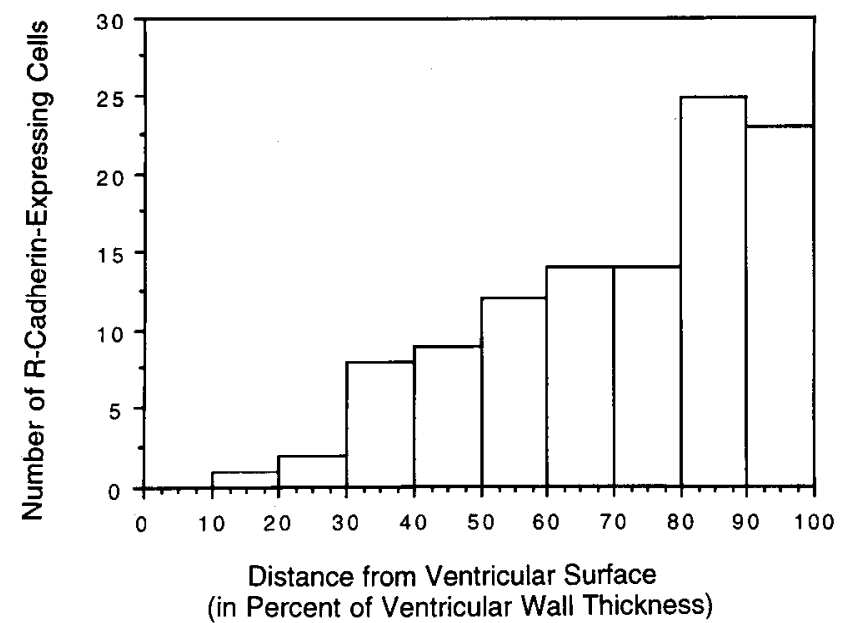

Figure 7. Histogram showing the distribution of R-cadherin-positive cell bodies in the ventricular zone of the E4-E4.5 mid-hypothalamic region. The number of R-cadherin-expressing cells is plotted as a function of the distance of their cell bodies from the ventricular surface (ependymal lining). This distance is expressed as percentage of the ventricular zone thickness. The mantle zone begins at $100 \%$ distance from the ventricular surface. The number of R-cadherin-positive cell bodies increases as the mantle zone is approached.

dorsocaudal region (area R8 in Fig. $2 A, B$ ). At stage E5, R-cadherin expression increases in intensity in a gradient-like fashion up to the location of the boundary to the adjacent pretectal neuromere (pt), where expression shows a steep decline (Figs. $2 A, B$; $3 E$ ). Note that there is also a stripe of expression in the isthmic area (RI0), which represents the boundary between the mes- and metencephalon.

The neuromere boundaries in the hypothalamus are less well defined in the chicken. According to most investigations, there are several longitudinal as well as transverse neuromeric domains in the vertebrate hypothalamus resulting in a mosaic-like pattern of neuromeres (Palmgren, 1921; Rendahl, 1924; Bergquist and Källén, 1953a,b, 1954; Keyser, 1972; Kuhlenbeck, 1973; Puelles et al., 1987; Bulfone et al., 1993; Figdor and Stern, 1993; Puelles and Rubenstein, 1993). The position of some of the R-cadherinpositive stripes in the chicken hypothalamus may be related to the location of the longitudinal domains in the neuromeric model by Puelles and Rubenstein (1993). For example, areas R3, R4, and $\mathrm{R} 5$ run approximately parallel to the longitudinal axis of the vertebrate brain, which, according to Puelles and Rubenstein, follows the curvature of the neural tube and terminates posterior to the optic stalk entry. Note that areas R3 and R7 share a sharp boundary of R-cadherin expression on one side, which may correspond to a neuromere boundary (Fig. $2 A, C$ ).

Some of the neuromere boundaries mentioned above restrict lineage and migration of neuroepithelial cells (Figdor and Stern, 1993). Assuming that migrating neuroepithelial cells express the same cadherin as their surroundings, the homophilic binding mediated by, for example, R-cadherin may restrict the migration of R-cadherin-expressing neuroblasts across borders of its expression.

R-cadherin expression extends across several of the forebrain sulci to terminate in the immediate vicinity of the sulci, for example, in the case of the anterior intraencephalic sulcus (sa in Fig. $1 A, B$ ) or of the medial diencephalic sulcus (sm in Fig. $3 C, D$ ) (Kuhlenbeck, 1937). In several other tissues, the differential expression of cadherins in epithelia coincides with specific morphogenetic changes and cell movements (reviewed in Takeichi, 1988,
1991). The expression of R-cadhcrin across somc of the sulci may therefore play a direct morphogenetic role in the formation or stabilization of the sulci. In this context, it has been argued that the sulci themselves do not represent neuromere boundaries (Northcutt and Butler, 1993; Puelles and Rubenstein, 1993).

\section{$R$-cadherin is expressed by postmitotic neuroblasts in the ventricular zone}

According to several studies (Bergquist, 1932, 1953; Keyser, 1972; Puelles et al., 1987), the diencephalic neuromeres represent independent morphogenetic fields where neuroblasts are generated. Focusing on the mid-hypothalamic (tuberal) region (areas R5 and R6 in Fig. 2A,C) (Kuenzel and van Tienhoven, 1982), we studied the expression of R-cadherin on the single-cell level in the E3-E5 embryo. The following results suggest that R-cadherin is expressed by postmitotic migrating neuroblasts in the ventricular zone in this area. (1) The vast majority of R-cadherin ex pressing cells in the ventricular zone coexpress the neuroblast marker Ng-CAM/8D9/G4 (Figs. 5D, 6C,D) (Grumet and Edelman, 1984; Thiery et al., 1985; Rathjen et al., 1987; Weikert et al., 1990; Grumet, 1992; Lemmon and McLoon, 1986) and show varying degrees of AChE activity (Fig. 8) (Miki and Mizoguti, 1982; Mizoguti and Miki, 1985; Layer and Sporns, 1987), which is also a neuroblast marker. (2) The frequency of the R-cadherinexpressing cell bodies increases as the mantle zone is approached (Fig. 7). (3) Only a very small percentage of R-cadherin-expressing cells undergo cell division (Fig. $2 E$ ). (4) R-cadherin-expressing cells and radial glia are two distinct cell populations (Figs. $5 B, 6 A, B)$.

In several respects, the $\mathrm{R}$-cadherin-expressing ventricular cells resemble neuroblasts migrating along radial glial processes in layered structures of the brain, such as in developing mammalian cortex and cerebellum (Hatten 1990, 1993; Rakic et al., 1994). Both types of cells are bipolar with one process extending inward to the ependymal layer (where it often forms an endfoot) and the other process leading outward into the mantle zone (Figs. 4I, 8A) (Morest, 1970; Rakic, 1972). In addition, the processes of some R-cadherin-expressing cells are in close contact with radial glial processes (Fig. $5 C$ ). Whether this contact is direct, as shown by electron microscopy for cell migration in cortical structures (Rakic, 1972), remains to be investigated. The ubiquitous expression of $\mathrm{N}$-cadherin by cells in the ventricular zone (Fig. 9B,D), where the cell bodies of radial glia are located, indicates that radial glia in this region might express $\mathrm{N}$-cadherin, as has been observed for other brain regions (Redies et al., 1993). The (relatively weak) heterophilic binding between Nand R-cadherin (Inuzuka et al., 1991; Matsunami et al., 1993; Redies and Takeichi, 1993a) may play a role in the migration of R-cadherin-expressing neuroblasts on the radial glial processes.

\section{$R$ - and $N$-cadherin-expressing cells in the mantle zone segregate and aggregate into separate diencephalic nuclei}

$\mathrm{R}$-cadherin is expressed by differentiating neuroblasts not only during their outward migration in the ventricular zone, but also in the mantle zone during brain nucleus formation (Figs. 4, 9). In parallel to the R-cadherin-expressing cells, N-cadherin-expressing neuroblasts accumulate in the mantle zone with a similar time course and frequency (Fig. 9). In the mid-hypothalamic region, $\mathrm{R}$ - and $\mathrm{N}$-cadherin-expressing cells are among the first neuroblasts to reach the mantle zone at E3-E3.5 (Figs. $4 A, B$; $9 A, B)$. At E3.5, the two populations overlap. As the mantle zone 

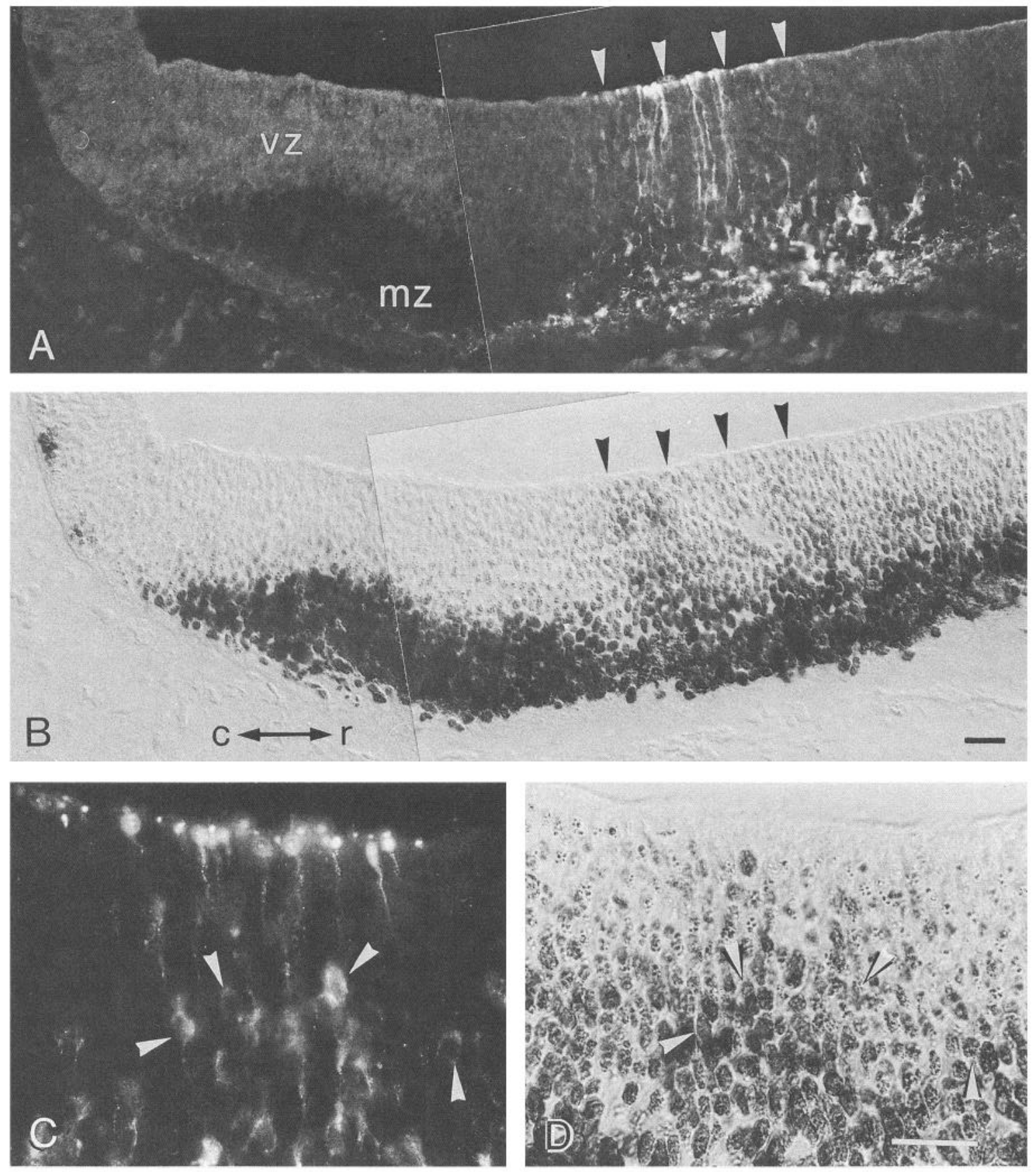

Figure 8. Double-staining for R-cadherin $(A, C)$ and acetylcholinesterase (AChE) activity $(B, D)$. The dark precipitate in $B$ and $D$ represents AChE activity. Arrowheads in $A$ and $B$ mark the region where R-cadherin-expressing cells are seen in the ventricular zone. Note that, in this region, AChE activity also extends into the ventricular zone (arrowheads in $A$ and $B$ ). A few of the cells displaying AChE activity express R-cadherin (arrowheads in $C$ and $D$ ). $c$, caudal; $m z$, mantle zone; $r$, rostral; $v z$, ventricular zone. Scale bars, $0.02 \mathrm{~mm}(B$ for $A$ and $B ; D$ for $C$ and $D$ ).

increases in thickness, more and more R- and N-cadherin-expressing neuroblasts accumulate. Between E3 and E4, these cells are restricted to one particular area that seems to split into two areas between E4 and E5 (areas R5 and R6 in Fig. 2A,C). In addition, at E5, the $\mathrm{R}$ - and $\mathrm{N}$-cadherin-expressing cells have almost entirely segregated to form two pairs of neuroblast clusters. These in vivo observations have direct in vitro correlates. Cell culture aggregation studies demonstrated that, when mixed, $\mathrm{N}$ - and R-cadherin-expressing cells can adhere to each other by a (weaker) heterophilic binding mechanism but, as aggregation proceeds, the two populations sort out to form separate clusters due to the (stronger) homophilic binding between the cells of each type (Inuzuka et al., 1991; Matsunami et al., 1993).

\section{Cadherin-mediated formation of nuclei and the transition between neuromeric and functional organization in the vertebrate brain}

In other brain regions, the expression of $\mathrm{R}$ - and $\mathrm{N}$-cadherin is also restricted to particular developing nuclei in the vertebrate embryo (Redies and Takeichi, 1993b; Redies et al., 1993). Since cadherins mediate cell-cell adhesion by a homophilic mechanism, our present observations support the hypothesis that cad- 

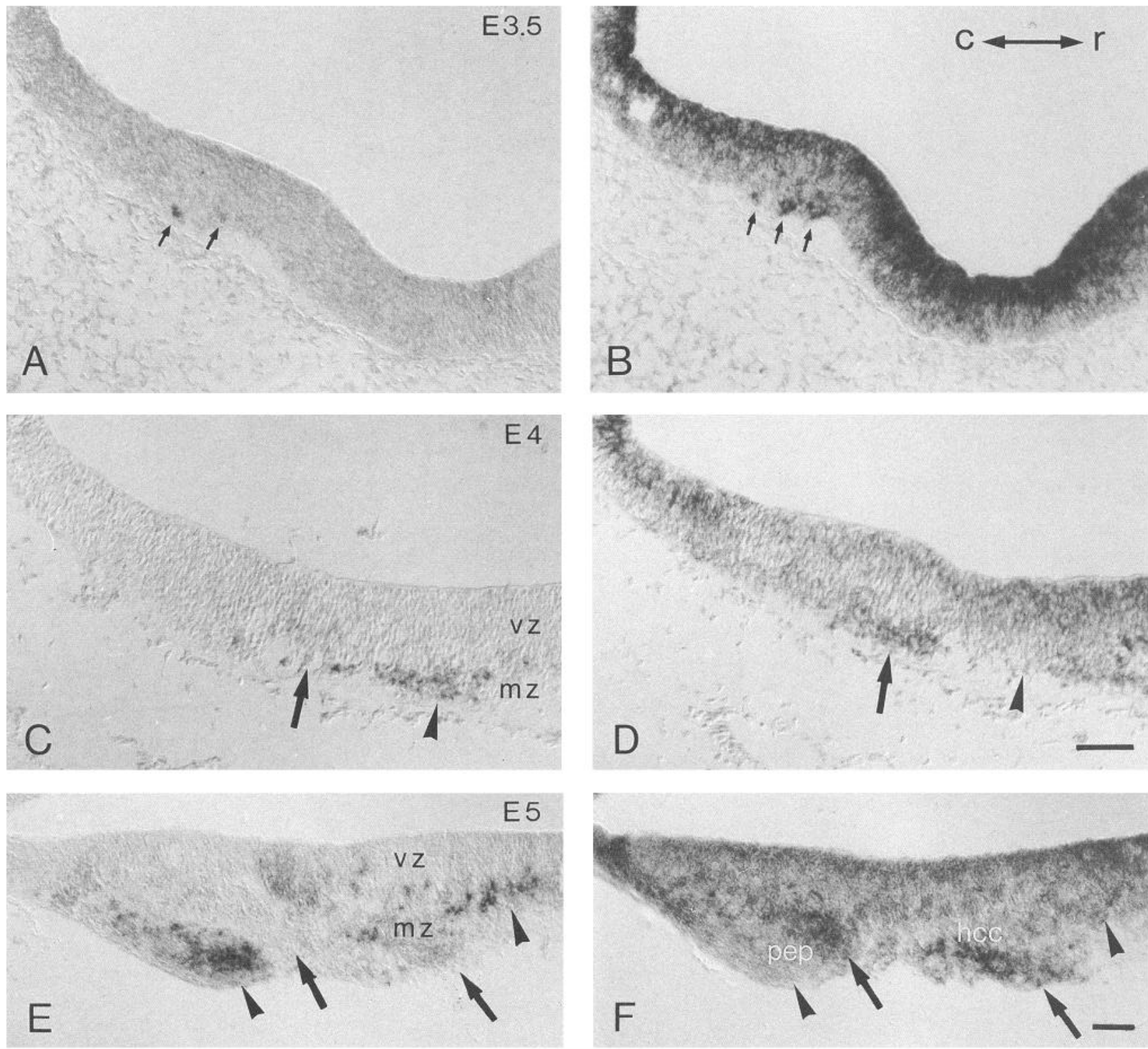

Figure 9. Nomarski optical images of sections hybridized in situ with digoxigenin-labeled antisense RNA probe for R-cadherin $(A, C$, $E$ ) and N-cadherin mRNA $(B, D, F)$. Transverse sections through the hypothalamus of different developmental stages (E3.5, E4, and E4.5) are shown; the developmental stages are indicated on the upper right corner of the left panels. For R-and N-cadherin in situ hybridization adjacent sections were used. N- and R-cadherin mRNA is visualized by a dark precipitate. The arrows in $A$ and $B$ point at R-and N-cadherin-positive cell bodies, respectively, in the developing mantle zone. In $C-F$, arrows mark the $\mathrm{N}$-cadherin-positive regions, and arrowheads the $\mathrm{R}$-cadherin-positive regions. $c$, caudal; $E$, embryonic day; $h c c$, hypothalamic cell cord; $m z$, mantle zone; pep, posterior entopeduncular area; $r$, rostral; $v z$, ventricular zone. Scale bars, $0.05 \mathrm{~mm}(D$ for $A-D ; F$ for $E$ and $F)$.

herins play a role in the aggregation of neuroblasts during the formation of brain nuclei (Redies et al., 1993). It remains to be determined whether other cadherins (Takeichi et al., 1990; Ranscht, 1991; Suzuki et al., 1991; Sano et al., 1993), or noncadherin adhesion molecules, are also expressed in particular developing brain nuclei. In this context, it is of interest that some of the G4-positive neuroblasts of the ventricular zone do not express R-cadherin (arrows in Figs. $5 D, 6 C, D$ ). These neuroblasts could conceivably express other cadherins, for example, E-cadherin, which is also expressed by ventricular cells (Shimamura and Takeichi, 1992).

In the mature chicken brain, most of the R- and N-cadherinpositive brain nuclei originating in the different neuromeres are connected to each other by fiber tracts to form parts of particular functional systems and neural circuits (Redies et al., 1993; Arndt and Redies, unpublished observations). The generation of neuroblasts in the different neuromeres and their aggregation into particular brain nuclei represent a crucial step in the morphogenetic transition from the early neuromeric to the late functional organization of the vertebrate brain. The present study identifies R-cadherin as one of the candidate molecules regulating this transition.

\section{References}

Altman J, Bayer SA (1978) Development of the diencephalon in the rat. I. Autoradiographic study of the time of origin and settling patterns of neurons of the hypothalamus. J Comp Neurol 182:945-972. 
Auerbach R, Kubai L, Knighton D, Folkman J (1974) A simple procedure for the long-term cultivation of chicken embryos. Dev Biol 41:391-394.

Bergquist H (1932) Zur Morphologie des Zwischenhirns bei niederen Wirbeltieren. Acta Zool (Stockh) 13:57-303.

Bergquist H (1953) On the development of diencephalic nuclei and certain mesencephalic relations in Lepidochelys olivacea and other reptiles. Acta Zool (Stockh) 34:155-190.

Bergquist H (1957) Mitotic activity during sucessive migrations in the diencephalon of chick embryos. Experientia 13:84-86.

Bergquist H, Källén B (1953a) Studies on the topography of the migration areas in the vertebrate brain. Acta Anat (Basel) 17:353-369.

Bergquist H, Källén B (1953b) On the development of neuromeres to migration areas in the vertebrate cerebral tube. Acta Anat (Basel) 18: $65-73$.

Bergquist H, Källén B (1954) Notes on the early histogenesis and morphogenesis of the central nervous system of vertebrates. J Comp Neurol 100:627-660

Bulfone A, Puelles L, Porteus MH, Frohmann MA, Martin GR, Rubenstein JLR (1993) Spatially restricted expression of Dlx-1, Dlx-2 (Tes-1), Gbx-2, and Wnt-3 in the cmbryonic day 12.5 mouse forebrain defines potential transverse and longitudinal segmental boundaries. J Neurosci 13:3155-3172.

de la Rosa EJ, Kayyem JF, Roman JM, Stierhof Y-D, Dreyer WJ, Schwarz U (1990) Topographically restricted appearance in the developing chick retinatectal system of Bravo, a neural surface protein: experimental modulation by environmental cues. J Cell Biol 111: 3087-3096.

Dräger UC, Edwards DL, Barnstable CJ (1984) Antibodies against filamentous components in discrete cell types of the mouse retina. $\mathbf{J}$ Neurosci 4:2025-2042.

Figdor MC, Stern CD (1993) Segmental organization of embryonic diencephalon. Nature 363:630-634.

Fujita S (1964) Analysis of neuron differentiation in the central nervous system by tritiated thymidine autoradiography. J Comp Neurol $122: 311-328$.

Geiger B, Ayalon O (1992) Cadherins. Annu Rev Cell Biol 8:307332.

Goodman CS, Shatz CJ (1993) Developmental mechanisms that generate precise patterns of neuronal connectivity. Cell [Suppl] 72:7798.

Grumet M (1992) Structure, expression and function of Ng-CAM, a member of the immunoglobulin superfamily involved in neuron-neuron and neuron-glia adhesion. J Neurosci Res 31:1-13.

Grumet M, Edelman GE (1984) Heterotypic binding between neuronal membrane vesicles and gial cells is mediated by a specific cell adhesion molecule. J Cell Biol 98:1746-1756.

Grunwald GB (1993) The structural and functional analysis of cadherin calcium-dependent cell adhesion molecules. Curr Opin Cell Biol 5:797-805.

Hamburger V, Hamilton $H$ (1951) A series of normal stages in the development of the chick embryo. J Morphol 88:49-92.

Hatta K, Takagi S, Fujisawa H, Takeichi M (1987) Spatial and temporal expression pattern of $\mathrm{N}$-cadherin cell adhesion molecules correlated with morphogenetic processes of chicken embryos. Dev Biol 120: 215-227.

Hatta K, Nose $\Lambda$, Nagafuchi A, Takeichi M (1988) Cloning and expression of cDNA encoding a neural calcium-dependent cell adhesion molecule: its identity in the cadherin gene family. J Cell Biol 106: 873-881.

Hatten M (1990) Riding the glial monorail: a common mechanism for glial-guided neuronal migration in different regions of the developing mammalian brain. Trends Neurosci 13:179-184.

Hatten M (1993) The role of migration in central nervous system neuronal development. Curr Opin Neurobiol 3:38-44.

Inuzuka H, Miyatani S, Takeichi M (1991) R-cadherin: a novel $\mathrm{Ca}^{2+}$ dependent cell-cell adhesion molecule expressed in the retina. Neuron 7:69-79.

Karnovsky MJ, Roots JL (1964) A 'direct-coloring' thiocholine method for cholinesterases. J Histochem Cytochem 12:219-221.

Karten HJ, Dubbeldam JL (1973) The organization and projection of the paleostriatal complex in the pigeon (Columba livia). J Comp Neurol 148:61-90.

Keyser A (1972) The development of the diencephalon of the chinese hamster. Basel: Karger.
Krumlauf R, Mashall H, Studer M, Nonchev S, Sham MH, Lumsden A (1993) Hox homeobox genes and regionalisation of the nervous system. J Neurobiol 24:1328-1340.

Kuenzel WI, van Tienhoven A (1982) Nomenclature and location of avian hypothalamic nuclei and associated circumventricular organs. J Comp Neurol 206:293-313.

Kuhlenbeck H (1937) The ontogenetic development of the diencephalic centers in a bird's brain (chick) and comparison with the reptilian and mammalian diencephalon. J Comp Neurol 66:23-75.

Kuhlenbeck H (1973) The central nervous system of vertebrates, Vol 3, P II. Berlin: Karger.

Layer PG (1983) Comparative localization of acetylcholinesterases and pseudocholinesterase during morphogenesis of the chick brain. Proc Natl Acad Sci USA 80:6413-6417.

Layer PG, Sporns O (1987) Spatiotemporal relationship of embryonic cholinesterases with cell proliferation in chicken brain and eye. Proc Natl Acad Sci USA 84:284-288.

Lemmon V, McLoon SC (1986) The appearance of an L1-like molecule in chick primary visual pathway. J Neurosci 6:2987-2994.

Lumsden A (1990) The cellular basis of segmentation in the developing hindbrain. Trends Neurosci 13:329-335.

Lumsden A (1993) The establishment of positional identity in the developing nervous system. J Neurobiol 24:1253-1255.

Matsunami H, Miyatani S, Inoue 'I, Copeland NG, Gilbert DJ, Jenkins NA, Takeichi M (1993) Cell binding specificity of mouse R-cadherin and chromosomal mapping of the gene. J Cell Sci 106:401-409.

Miki A, Mizoguti H (1982) Proliferating ability, morphological development and acetylcholinesterase activity of the neural tube cells in early chick embryos. Histochemistry 76:303-314

Miyatani S, Shimamura K, Hatta M, Nagafuchi A, Nose A, Matsunaga M, Hatta K, Takeichi M (1989) Neural cadherin: role in selective cell-cell adhesion. Scicnce 245:631-635.

Mizoguti H, Miki A (1985) Interrelationship among the proliferating ability, morphological development and acetylcholinesterase activity of the neural tube cells in early chick embryos. Acta Histochem Cytochem 18:85-96.

Morest DK (1970) A study of neurogenesis in the forebrain of oppossum pouch young. Z Anat Entwicklungsgesch 130:265-305.

Nagafuchi A, Shirayoshi Y, Okazaki K, Yasuda K, Takeichi M (1987) Transformation of cell adhesion properties by exogenously introduced E-cadherin cDNA. Nature 329:341-343.

Northcutt RG, Butler AB (1993) The diencephalon and optic tectum of the longnose gar, Lepisosteus osseus (L.): cytoarchitectonics and distribution of acetylcholinesterase. Brain Behav Evol 41:57-81.

Nose A, Takeichi M (1986) A novel cadherin cell adhesion molecule: its expression patterns associated with implantation and organogenesis of mouse embryos. J Cell Biol 103:2649-2658.

Nose A, Nagafuchi A, Takeichi M (1988) Expressed recombinant cadherins mediate cell sorting in model systems. Cell 54:993-1001.

Palmgren A (1921) Embryological and morphological studies on the midbrain and cerebellum of vertebrates. Acta Zool (Stockh) 2:1-94.

Pouliot Y (1992) Phylogenetic analysis of the cadherin superfamily. Bioessays 14:743-748.

Puelles L, Rubenstein JLR (1993) Expression patterns of homeobox and other putative regulatory genes in the embryonic mouse forebrain suggest a neuromeric organization. Trends Neurosci 16:472-479.

Puelles L, Amat JA, Martinez-de-la-Torre M (1987) Segment-related, mosaic neurogenetic pattern in the forebrain and mesencephalon of early chick embryos: I. Topography of AChE-positive neuroblasts up to stage HHI8. J Comp Neurol 266:24\%-268.

Rakic P (1972) Mode of cell migration to the superficial layers of fetal monkey neocortex. J Comp Neurol 145:61-84.

Rakic P, Cameron RS, Komuro H (1994) Recognition, adhesion, transmembrane signaling and cell motility in guided neuronal migration. Curr Opin Neurnhiol 4:63-69.

Ranscht B (1991) Cadherin cell adhesion molecules in vertebrate neural development. Semin Neurosci 3:285-296.

Rathjen FG, Wolff JM, Frank R, Bonhocffer F, Rutishauscr U (1987) Membrane glycoproteins involved in neurite fasciculation. J Cell Biol 104:343-353.

Redies C, Gänzler S (1994) Neuromeric expression of R-cadherin and the formation of nuclei in the developing chicken forebrain. Soc Neurosci Abstr 20:252.

Redies C, Takeichi M (1993a) N- and R-cadherin expression in the optic nerve of the chicken embryo. Glia 8:161-171. 
Redies C, Takeichi M (1993b) Fxpression of N-cadherin mRNA during development of the mouse brain. Dev Dynam 197:26-39.

Redies C, Inuzuka H, Takeichi M (1992) Restricted expression of Nand R-cadherin on neurites of the developing chicken CNS. J Neurosci 12:3525-3534.

Redies C, Engelhart K, Takeichi M (1993) Differential expression of $\mathrm{N}$ - and R-cadherin in functional neuronal systems and other structures of the developing chicken brain. J Comp Neurol 333:398-416.

Rendahl H (1924) Embryologische und morphologische Studien über das Zwischenhirn beim Huhn. Acta Zool (Stockh) 5:241-344.

Rose JE (1942) The ontogenetic development of the rabbit's diencephalon. J Comp Neurol 77:61-129.

Sano K, Tanihara H, Heimark RL, Obata S, Davidson M, St. John T, Taketani S, Suzuki S (1993) Protocadherins: a large family of cadherin-mediated molecules in central nervous system. EMBO J 12:2249 2256.

Sauer FC (1935) Mitosis in the neural tube. J Comp Neurol 62:377406.

Shimamura K, Takeichi M (1992) Local and transient expression of E-cadherin involved in mouse embryonic brain morphogenesis. Development 116:1011-1019.

Suzuki S, Sano K, Tanihara H (1991) Diversity of the cadherin family: evidence for eight new cadherins in nervous tissue. Cell Regul 2:261270.

Takeichi M (1988) The cadherins: cell-cell adhesion molecules controlling animal morphogenesis. Development 102:639-655.
Takeichi M (1991) Cadherin cell adhesion molecules as a morphogenetic regulator. Science 251:1451-1455.

Takeichi M, Inuzuka H, Shimamura K, Fujimori T, Nagafuchi A (1990) Cadherin subclasses: differential expression and their roles in neural morphogenesis. Cold Spring Harbor Symp Quant Biol 55:319-325.

Thanos S, Bonhoeffer F (1983) Investigations on the development and topographic order of retinotectal axons: anterograde and retrograde staining of axons and perikarya with rhodamine in vivo. J Comp Neurol 219:420-430.

Thiery J-P, Delouvée $\Lambda$, Grumet M, Edelman GM (1985) Initial appearance and regional distribution of the neuron-glia cell adhesion molecule in the chick embryo. J Cell Biol 100:442-456.

Vaage S (1969) The segmentation of the primitive ncural tube in chick embryo (Gallus domesticus). Ergeb Anat Entwicklungsgesch 41:188.

Vanselow J, Thanos S, Godenuent P, Henke-Fahle S, Bonhoeffer F (1989) Spatial arrangement of radial glia and ingrowing retinal axons in the chick optic tectum during development. Dev Brain Res 45:1527.

von Baer KE (1828) Ueber die Entwicklungsgeschichte der Thiere, Vols 1-3. Königsberg.

Weikert 'T, Rathjen FG, Layer PG (1990) Developmental maps of acetylcholinesterase and G4-antigen of the early chicken brain: longdistance tracts originate from AChE-producing cell bodies. J Neurobiol 21:482-498.

Wilson SW, Placzek M, Furley AJ (1993) Border disputes: do boundaries play a role in growth-cone guidance? Trends Neurosci 16:316323. 